Environment Conservation Journal 14(3)161-168, 2013

ISSN 0972-3099 (Print) 2278-5124 (Online)

Abstracted and Indexed

\title{
Seasonal abundance and effect of abiotic factors on mango leaf hopper Amritodus atkinsoni (Leth.) population on wild and different cultivars of mango in Jammu region
}

Shakha Sharma $\bowtie$ and J.S Tara

Received: 17.08.2013

Accepted: 19.11.2013

\begin{abstract}
The mango leaf hopper Amritodus atkinsoni (Leth.) is a very serious pest of mango in J\&K region. A series of experiments were conducted on seasonal abundance and the influence of abiotic factors on the incidence of $A$. atkinsoni on wild and different cultivars of mango viz Dashehari, Langra, Malda and Amarpalli at Sher-e-Kashmir University of Agricultural Science and Technology Jammu, and, at a mango orchard at Nagbani. The mango hoppers (adults) started appearing with the panicle emergence during the months of February-March and reached its peak ranging from 9.6 to 14.2 in wild and all cultivars under study during May-June. After this the hopper population started declining, but showed another peak (6.6 to 9.8) during August-September which is comparatively lower than the previous one. This clearly indicates that the species breeds twice a year thus a bivoltine species. From September onwards, the hoppers went on declining and vanished by the end of December as they migrate to cracks and crevices of tree trunk and overwinter as adults. Abiotic factors such as maximum temperature $\left(X_{1}\right)$, minimum temperature $\left(X_{2}\right)$, morning relative humidity $\left(X_{3}\right)$, evening relative humidity $\left(\mathbf{X}_{4}\right)$ and rainfall $\left(\mathbf{X}_{5}\right)$ had much impact on the growth of hopper population. The hopper population correlated negatively and significantly with morning relative humidity $(r=-0.635$ to -0.816$)$ and evening relative humidity $(r=-0.289$ to -0.556$)$ and showed a significant positive correlation with mean maximum temperature $(r=0.692$ to 0.915$)$ and minimum temperature $(r=0.590$ to 0.881$)$ in wild and all four cultivars, whereas rainfall remained fluctuating throughout the study period thus didn't show any significant impact.
\end{abstract}

Keywords: Mango leaf hopper, seasonal abundance, abiotic factors, cultivars, panicle, multiple correlation coefficient, bivoltine, crevices

\section{Introduction}

Mango (Mangifera indica Linn.) is an important fruit crop and occupies an area of about 2.31 million hectares with an annual production of about 15.03 million tonnes in India (Anon, 2010). India accounts for 54 per cent of world's total mango production (Chauhan and Dabas 1997) and is the highest producer of this fruit (Srivastava 1998). As compared to the area under cultivation, its production is comparatively very low. Out of many factors, one of the major factors responsible for its low productivity is the threat of insect pests. Over 175-200 different species of insect pests have been reported attacking mango trees (Fletcher 1916,Vevai 1969, Butani 1974, Nair 1975, Nayar et al.1976 and Veeresh 1989).Out of all, mango leaf hoppers are the most harmful and economically important pest found in epidemic form in India (Anufriev 1970) and south east Asia (Ghauri 1967) Author's Address

P.G. Department of Zoology, University of Jammu,Jammu Email: shakha@live.in
Among many species of mango hoppers reported, Idioscopus clypealis, Idioscopus niveosparsus and Amritodus atkinsoni are the major infesters found persistent on panicle and leaves (Soomro et al. 1987).These hoppers mainly cause damage by sucking of sap from tender shoots, leaves, and inflorescence which ultimately effects the fruit setting (Chari et al. 1969 and Bindra et al. 1971). The infested flowers shrivel, turn brown and ultimately fall off (Hussain and Pruthi 1921, Lefroy 1906, Singh 1968 and Sathiyanandan et al., 1972). During feeding hoppers excrete a sticky secretion known as 'Honey dew' on which develops a sooty mould which interferes with the normal photosynthetic activity of the plant resulting in non setting of flower and dropping of immature fruits (Hussain and Pruthi 1921, Rao 1930, Kayashima 1934, Butani 1993 and Ayyar 1963). Injury is also caused due to the insertion of ovipositor for egg laying which results in drying and withering of such parts (Ayyar 1940, Butani1979 and 
Srivastava1997). Hussain and Pruthi (1921), Rao (1930), Wagle (1934) and Khan (1939), noted that the hoppers caused 20-100 percent yield loss. Cheema et al. (1954) and Gangolly et al. (1957) reported that the yield loss ranged from 25-30 per cent, whereas Wadhi and Batra (1964) and Reddy (1968) reported 25-60 per cent yield loss in general. As the knowledge of insect population fluctuation on its host in relation to physical environmental factors is quite useful for predicting pest population and ultimately the pest management, the present study has been carried out to note the effect of abiotic factors on hopper population in Jammu region.

\section{Material and methods}

The studies on the seasonal abundance and prediction of $A$. atkinsoni population in relation to physical environmental factors viz. maximum temperature $\left(\mathrm{X}_{1}\right)$ minimum temperature $\left(\mathrm{X}_{2}\right)$, morning relative humidity $\left(\mathrm{X}_{3}\right)$, evening relative humidity $\left(\mathrm{X}_{4}\right)$ and rainfall $\left(\mathrm{X}_{5}\right)$ were conducted on twenty five trees, five each of cultivars Dashehari $\left(\mathrm{Y}_{1}\right)$, Langra $\left(\mathrm{Y}_{2}\right)$, Malda $\left(\mathrm{Y}_{3}\right)$, Amarpalli $\left(\mathrm{Y}_{4}\right)$ at Sher-e-Kashmir university of Agricultural Science and Technology, Jammu and Wild $\left(\mathrm{Y}_{5}\right)$ at mango orchard, Nagbani in the year 2010. Five inflorescences per tree were tagged for conducting field observations on hopper population, each from four geographical directions and one from inner quadrant. Fortnightly data right from the appearance of hoppers was taken all around the year in all the cultivars till they vanished. Bag trap method (Verghese and Rao, 1987) was adopted for recording the nymphal population on the inflorescences till the end of April 2010. In the bag trap method, each inflorescence was covered with a polythene bag $(60 * 30 \mathrm{cms})$ provided with a cotton swap soaked in ethyl acetate. Both adults and nymphs were trapped inside the bags. They were brought to the entomology laboratory, University of Jammu and nymphs and adults were segregated and counted separately. After April when an adult hoppers outnumbered nymphs, the sweep net method was used for collecting the hoppers with the insect collecting net. The length of the handle of net was little more than a meter while the diameter of the bag of the net was $40 \mathrm{~cm}$. In all, 25 bag traps / sweeps from five plants of each cultivar and wild mango were made. Immediately after making a sweep, the loop of the net was rotated $90^{\circ}$ so as to avoid the exit of adult hoppers from the net. Hoppers thus collected were immediately transferred to insect killing bottle and were then counted and preserved. Simultaneously, observations on meteorological factors i.e maximum and minimum temperature, relative humidity (both morning and evening) and rainfall were recorded daily. Fortnightly average was calculated for all these factors before calculating Pearson's correlation coefficient and multiple correlation coefficient.

\section{Results and discussion}

During the observations conducted on fortnightly average hopper population, mean maximum temperature, minimum temperature, relative humidity and rainfall clearly indicates that during winters (January - March), no hoppers were seen on wild mango and all the four cultivars. The mean maximum and minimum temperature was recorded very low to the tune of $14.4^{\circ} \mathrm{C}-20.1^{\circ} \mathrm{C}$ and $4.3^{\circ} \mathrm{C}$ $7.9^{0} \mathrm{C}$ respectively, whereas relative humidity both morning (85.5\% to $94 \%)$ and evening (51.5\% to $72 \%$ ) was found comparatively high and rainfall recorded almost negligible $(0-11.5 \mathrm{~mm})$ (Table. 1, Fig. 1). Adult hoppers of species A. atkinsoni started appearing in the second fortnight of February with panicle emergence on Dashehari (0.8), Langra (0.6) and Malda (0.4), and, during the first fortnight of March on Amarpalli (1.2) and wild (0.8). Reddy (1968), Srivastava and Butani (1972), Patel et al.(1973 and1989), Jhala et al. (1988), Tandon (2001), Rahman and Kuldeep (2007) and Sharma and Sharma (2009 and 2011) also observed that adults of A. atkinsoni started appearing during the month of February-March. After this the population showed a peak during April on Dashehari (11.8) in May on Langra (9.6), Malda (14.2) and Amarpalli (13.6), and, during the month of June on wild mango (12.4). The mean maximum $\left(37.2^{0} \mathrm{C}-39.9^{\circ} \mathrm{C}\right)$ and minimum $\left(20.5^{\circ} \mathrm{C}\right.$ $24.5^{\circ} \mathrm{C}$ ) temperature was recorded very high during this period, whereas relative humidity both morning (52.5-57\%) and evening (18-30\%) was observed comparatively low. All the above results are in consonance with the findings of Palo and Garcia (1936), Patel et al. (1990), Hiremath and Hiremath 
(1994), Tandon (2001), Babu et al. (2002), Fletcher and Dangerfield (2002), Pezhman and Radjabi (2002), Dwevedi et al.(2003), Anithakumari et in the hopper population with the slight fall in mean al.(2009), Sharma and Sharma (2009 and 2011), minimum and maximum temperature and increase Sharma et al. (2010), After this a fall was noticed in (morning and evening) relative humidity.

Table 1: Effect of abiotic factors on seasonal abundance of Amritodus atkinsoni (adults) on wild and different cultivars of mango in Jammu Region (January -December 2010)

\begin{tabular}{|c|c|c|c|c|c|c|c|c|c|c|}
\hline \multirow[b]{2}{*}{$\begin{array}{l}\text { YEAR 2010 } \\
\text { (MONTHS) }\end{array}$} & \multicolumn{5}{|c|}{$\begin{array}{l}\text { MEAN NUMBER OF ADULT } \\
\text { HOPPERS }\end{array}$} & \multicolumn{2}{|c|}{ TEMP $\left(\right.$ in $\left.{ }^{\circ} \mathbf{C}\right)$} & \multicolumn{2}{|c|}{$\begin{array}{l}\text { RELATIVE } \\
\text { HUMIDITY } \\
\end{array}$} & \multirow[b]{2}{*}{$\begin{array}{c}\text { TOTAL } \\
\text { RAINFALL } \\
\quad(\mathbf{m m})\end{array}$} \\
\hline & 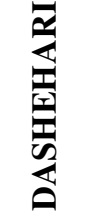 & 㞼 & 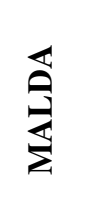 & $\frac{3}{3}$ & 㝵 & $\sum$ & 当 & 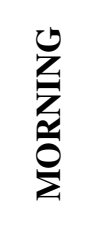 & 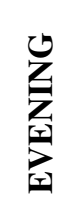 & \\
\hline Jan 1-15 & 0 & 0 & 0 & 0 & 0 & 14.4 & 4.45 & 94 & 72 & 2.8 \\
\hline 15-30 & 0 & 0 & 0 & 0 & 0 & 17.7 & 4.3 & 90.5 & 58 & 0 \\
\hline Feb 1-15 & 0 & 0 & 0 & 0 & 0 & 20.1 & 7.9 & 85.5 & 51.5 & 11.5 \\
\hline 15-29 & 0.8 & 0.6 & 0.4 & 0 & 0 & 23.6 & 8.1 & 83.5 & 43 & 0 \\
\hline Mar 1-15 & 1.4 & 1.4 & 2.4 & 1.2 & 0.8 & 26.05 & 11.5 & 79.5 & 43 & 2.1 \\
\hline $15-31$ & 2.2 & 2.2 & 2.8 & 3 & 2.4 & 33.1 & 15.2 & 77 & 38 & 0.9 \\
\hline Apr 1-15 & 5.6 & 5.2 & 6.6 & 5.8 & 4.4 & 36.7 & 16.7 & 57.5 & 21 & 0 \\
\hline $15-30$ & 11.8 & 8.2 & 13.6 & 11.2 & 7.8 & 37.7 & 20.5 & 53 & 23 & 0.4 \\
\hline May 1-15 & 9.4 & 9.6 & 14.2 & 12.4 & 9.2 & 37.2 & 21.5 & 57 & 30 & 9.6 \\
\hline $15-31$ & 7.8 & 7.2 & 7.6 & 13.6 & 11.8 & 39.7 & 22.5 & 52.5 & 18 & 12 \\
\hline Jun 1-15 & 5.2 & 6.2 & 5.4 & 10.2 & 12.4 & 38 & 22.3 & 53.5 & 24 & 6.1 \\
\hline 15-30 & 4.2 & 5.4 & 4.2 & 7.6 & 10.2 & 39.9 & 24.5 & 58 & 34 & 29.8 \\
\hline Jul 1-15 & 3.2 & 2.6 & 3 & 4.6 & 8.6 & 36.3 & 23.9 & 73.5 & 50 & 47.5 \\
\hline $15-31$ & 4.6 & 2.6 & 2.8 & 3.8 & 7.4 & 33.1 & 24.2 & 87 & 72 & 106.4 \\
\hline Aug 1-15 & 5.6 & 3.4 & 5.2 & 2.8 & 9.8 & 33.5 & 24.5 & 85 & 73 & 117.6 \\
\hline $15-31$ & 6.6 & 4.6 & 5.8 & 4.8 & 8.2 & 33.7 & 24.9 & 87 & 68.5 & 144.4 \\
\hline Sep 1-15 & 7.4 & 7.4 & 6.4 & 6.2 & 6.8 & 32.8 & 23.1 & 90 & 66 & 6.1 \\
\hline 15-30 & 5.2 & 5.8 & 7.2 & 6.6 & 6.2 & 32.3 & 20.55 & 86 & 58 & 10.8 \\
\hline Oct $1-15$ & 3.8 & 4.4 & 3.8 & 5.2 & 5.2 & 33 & 19.85 & 84.5 & 48 & 1 \\
\hline 15-31 & 3.6 & 3.6 & 3.8 & 4.2 & 3.8 & 30.3 & 16.65 & 85.5 & 47 & 12.1 \\
\hline Nov 1-15 & 2.4 & 3 & 1.8 & 3.4 & 3.6 & 28.1 & 10.8 & 91 & 37.5 & 0 \\
\hline $15-30$ & 2 & 1.6 & 0.8 & 3 & 3 & 24.75 & 8.65 & 93.5 & 39.5 & 0.5 \\
\hline Dec 1-15 & 2 & 0.6 & 0.4 & 1.6 & 1.6 & 21.55 & 5.2 & 95.5 & 45 & 3.6 \\
\hline $15-31$ & 0 & 0 & 0 & 0.6 & 0 & 19.65 & 3.7 & 95.5 & 49.5 & 33.7 \\
\hline
\end{tabular}

Second peak was also recorded on wild and all four (6.6). On wild (9.8) this second peak was seen cultivars in the month of September on Dashehari during the month of August, thus showing two (7.4), Langra (7.4), Malda (7.2), and Amarpalli breeding periods in a year. These observations are in line with the observations recorded by Srivastava 
and Butani (1972), Tandon (2001) and Sharma and Sharma (2009 and 2011). The results are contrary to the findings of Dalvi and Dumbre (1994) who reported that this species bred thrice in Maharashtra. After this, the hopper population showed a continuous fall and vanished till the end of December on wild and all cultivars as it reportedly migrated to cracks and crevices of the trunk and overwinters in adult stage. Similar observations have been noticed by Hussain and Pruthi (1924), Rahman (1939), Patel and Telgiri (1950), Gangolly et al.(1957), Pruthi and Batra (1960), Reddy (1968), Patel et al. (1975), , Patel et al. (1994), Tandon (2001), Babu et al.(2002),
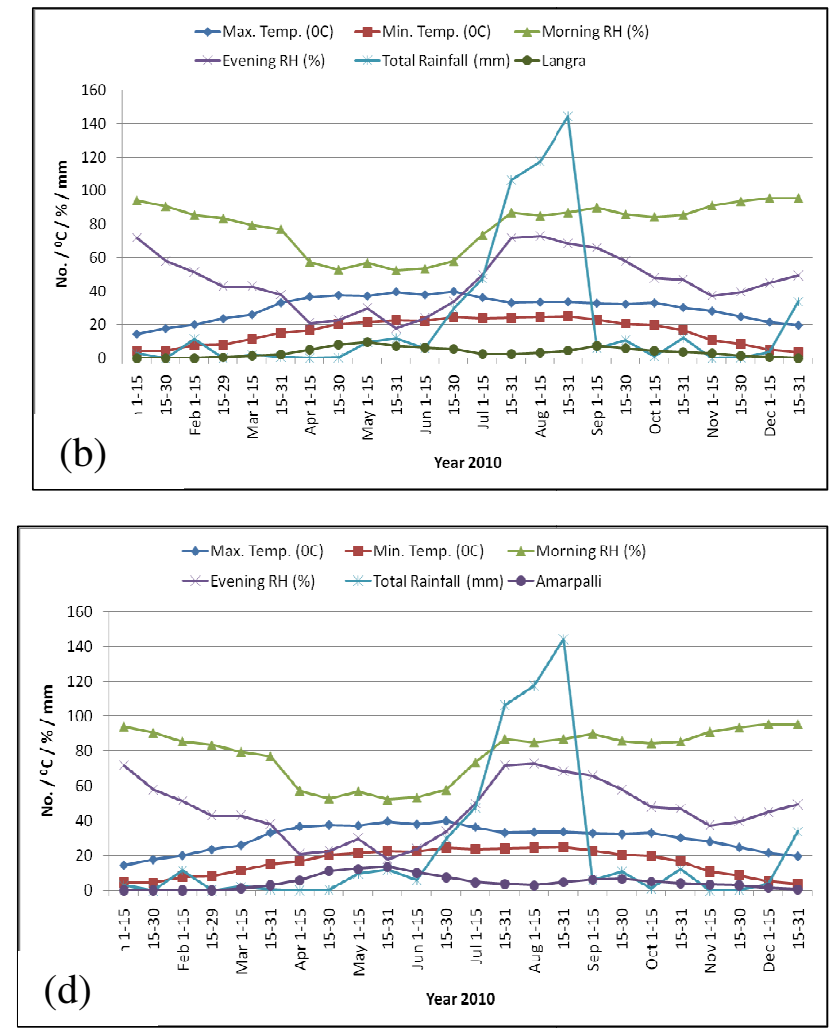

Rahman and Kuldeep (2007), and, Sharma and Sharma (2009 and 2011) (Table. 1, Fig. 1).
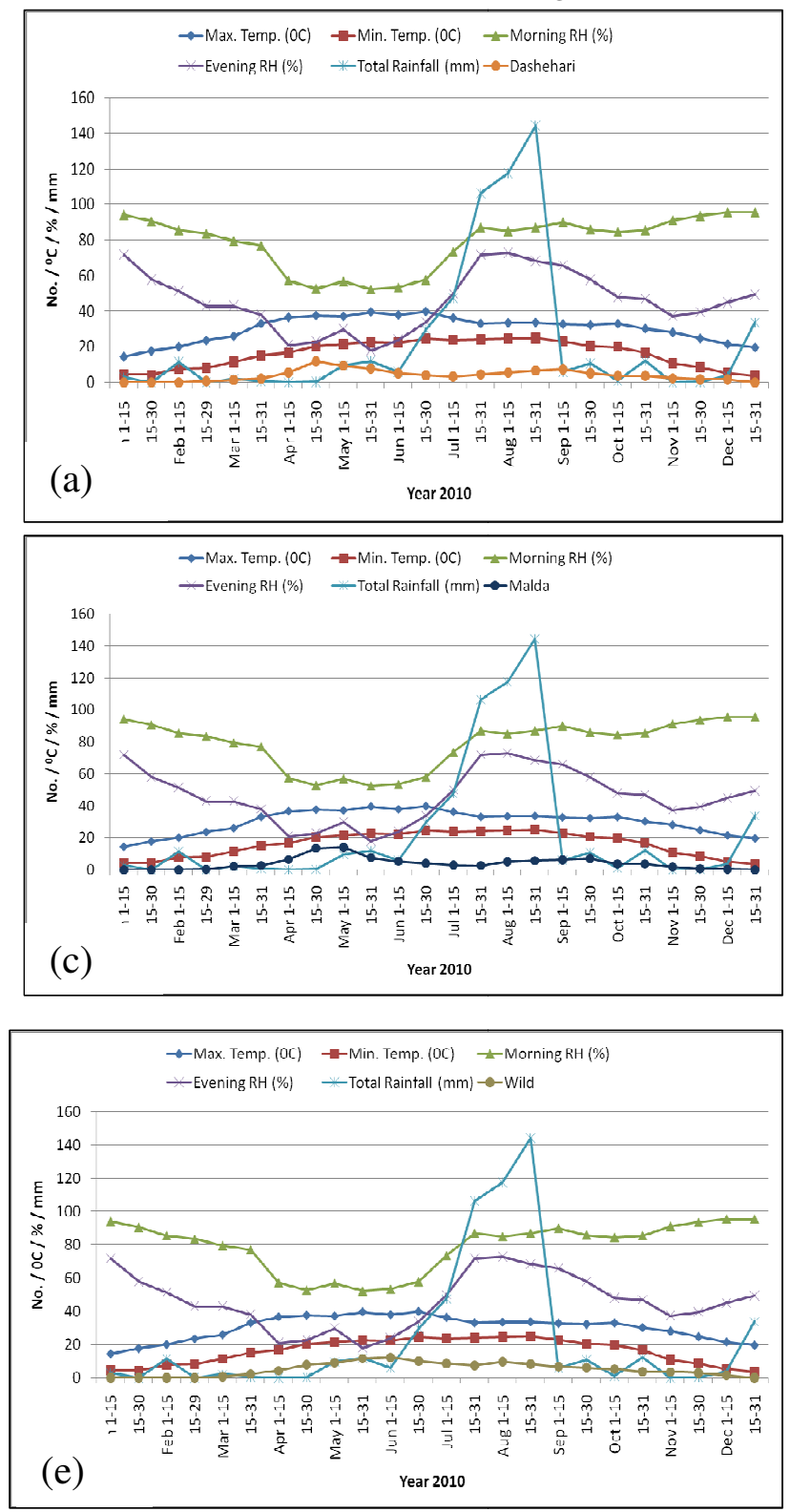

Fig 1. Effect of abiotic factors on seasonal abundance of Amritodus atkinsoni (adults) on Dashehari (a), Langra (b), Malda (c), Amarpalli (d), and wild (e) in Jammu Region (January - December 2010).

Average maximum temperature showed a positive significant. The ' $r$ ' value has been calculated as significant correlation with the hopper population $0.711,0.735,0.590,0.659$ and 0.881 in Dashehari, with ' $r$ ' value recorded as 0.780 in Dashehari, Langra, Malda, Amarpalli and wild respectively. 0.805 in Langra, 0.692 in Malda, 0.811 in All these findings are in parallel with the findings Amarpalli and 0.915 in wild which is highly of Mackenna (1919), Sood et al. (1971), Sheikh et significant with hopper population. Average al.(1993), Tandon (2001) and Anithakumari et minimum temperature is also positively correlated al.(2009) (Table. 2, Fig. 2) .

with the hopper population and is highly 
Table 2: Correlation co-efficient between Amritodus atkinsoni population and abiotic factors on wild and different cultivars of mango in Jammu Region (January-December 2010)

\begin{tabular}{|c|c|c|c|c|c|}
\hline \multirow{2}{*}{ Cultivars } & \multicolumn{2}{|c|}{ Temperature } & \multicolumn{2}{|c|}{ Relative humidity } & \multirow{2}{*}{ Total Rainfal } \\
\hline & Max. & Min. & Morning & Evening & \\
\hline DASHEHARI & $0.780 * *$ & $0.711 * *$ & $-0.635 * *$ & -0.289 & 0.286 \\
\hline LANGRA & $0.805 * *$ & $0.735 * *$ & $-0.689 * *$ & -0.351 & 0.187 \\
\hline MALDA & $0.692 * *$ & $0.590 * *$ & $-0.648 * *$ & -0.349 & 0.107 \\
\hline AMARPALLI & $0.811 * *$ & $0.659 * *$ & $-0.816 * *$ & $-0.556 * *$ & -0.018 \\
\hline WILD & $0.915 * *$ & $0.881 * *$ & $-0.777 * *$ & -0.337 & 0.318 \\
\hline
\end{tabular}

*Significant at $\mathbf{p}=\mathbf{0 . 0 5}$

Significant at $\mathbf{p}=\mathbf{0 . 0 1}$

Fig. 2. Correlation coefficient between Amritodus atkinsoni population and abiotic factors on wild and different cultivars of mango in Jammu Region (January-December 2010)

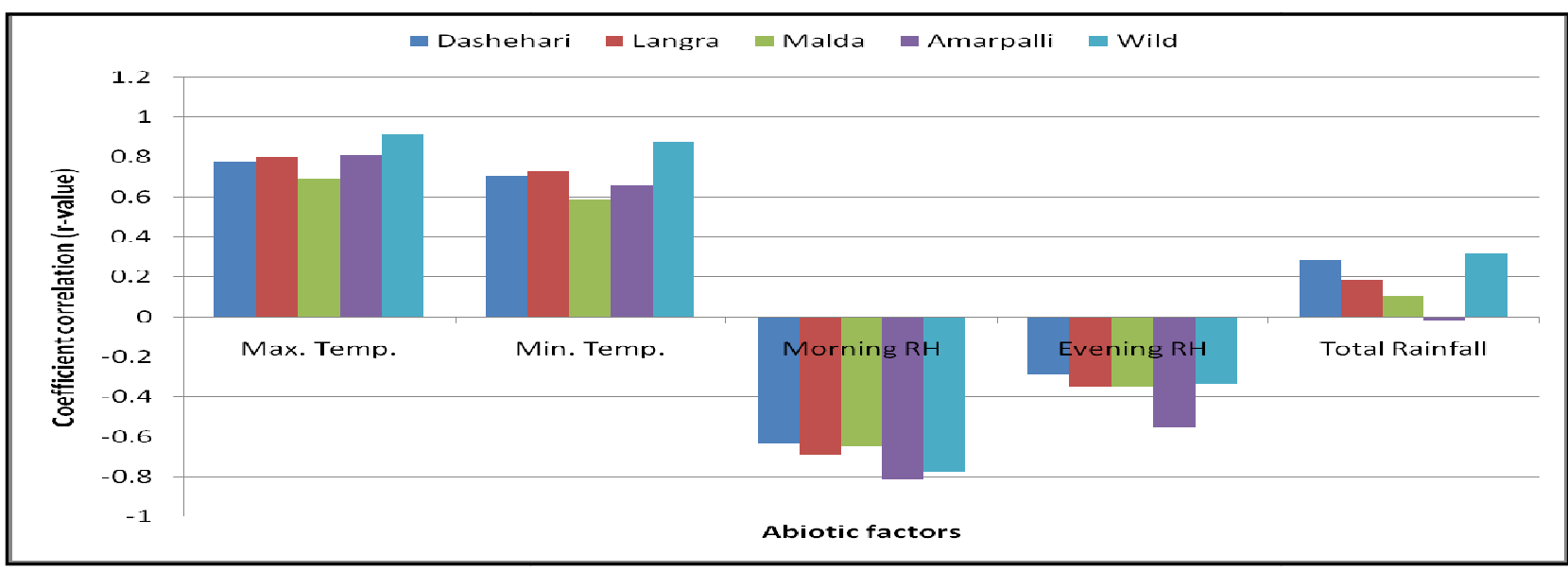

Relative humidity (both morning and evening) in this case showed a negative correlation with high degree of significance during morning hours. The ' $r$ ' value for morning relative humidity has been found to be $-0.635,-0.689,-0.648,-0.816$ and 0.777 , whereas for evening relative humidity, the ' $r$ ' value observed to the tune of - $0.289,-0.351$, 0.349, - 0.556 and - 0.337 for Dashehari, Langra, Malda, Amarpalli and wild respectively. Average rainfall showed a great fluctuation in its value and did not appear to have any significant impact on hopper population (Table 2; Fig - 6). Lefroy (1906), Sen and Prasad (1954), Tandon et al.(1983), Singh (1992), Patel et al.(1994), Haseeb (1998), Tandon (2001), Sharma (2002), Talpur et.al.(2002), Kannan and Rao (2006), Pushpalatha et al.(2008), Anitha Kumari et al.(2009), Vijaya et al.(2010) and Joshi and Kumar (2012) also reported that the hopper population was positively correlated with maximum temperature and negatively correlated with relative humidity. Thus the present findings are in conformity with the above findings. Rainfall on the other hand remained fluctuating thus did not have any significant impact on the growth of hopper population. The combined effect of abiotic factors on hopper population showed that the weather parameters had influenced $A$. atkinsoni population significantly to a minimum of 90.6 percent $(\mathrm{R}=$ $0.906)$ in Malda to the maximum of 95.8 percent $(\mathrm{R}$ $=0.958)$ in wild whereas it varied from 91.0 percent $(\mathrm{R}=0.910)$ in Langra to 91.5 percent $(\mathrm{R}=$ 0.915) in Amarpalli and 93.7 percent $(\mathrm{R}=0.937)$ in Dashehari respectively (Table-3). 
Table 3: Multiple correlation coefficient between Amritodus atkinsoni population and abiotic factors on wild and different cultivars of mango in Jammu Region (JanuaryDecember 2010)

\begin{tabular}{|l|ll|}
\hline $\mathbf{Y}_{1}$ & $-16.646+1.153 \mathrm{X}_{1}-0.883 \mathrm{X}_{2}-0.137 \mathrm{X}_{3}+0.229 \mathrm{X}_{4}+0.010 \mathrm{X}_{5} \quad(\mathrm{R}=0.843)^{*}$ \\
\hline $\mathbf{Y}_{2}$ & $-4.702+0.512 \mathrm{X}_{1}-0.270 \mathrm{X}_{2}-0.092 \mathrm{X}_{3}+0.096 \mathrm{X}_{4}+0.00 \mathrm{X}_{5}$ & $(\mathrm{R}=0.827)^{*}$ \\
\hline $\mathbf{Y}_{3}$ & $-20.674+1.552 \mathrm{X}_{1}-1.267 \mathrm{X}_{2}-0.227 \mathrm{X}_{3}+0.356 \mathrm{X}_{4}-0.007 \mathrm{X}_{5}$ & $(\mathrm{R}=0.785)^{*}$ \\
\hline $\mathbf{Y}_{4}$ & $-0.174+0.578 \mathrm{X}_{1}-0.292 \mathrm{X}_{2}-0.148 \mathrm{X}_{3}+0.087 \mathrm{X}_{4}-0.011 \mathrm{X}_{5}$ & $(\mathrm{R}=0.872)^{*}$ \\
\hline $\mathbf{Y}_{5}$ & $7.862+0.116 \mathrm{X}_{1}+0.192 \mathrm{X}_{2}-0.130 \mathrm{X}_{3}+0.013 \mathrm{X}_{4}+0.014 \mathrm{X}_{5}$ & $(\mathrm{R}=0.956)^{*}$ \\
\hline
\end{tabular}

"Significant at $\mathrm{p}=\mathbf{0 . 0 5}$

$\mathbf{Y}_{1}=$ Dashehari, $\mathbf{Y}_{2}=$ Langra, $\mathbf{Y}_{3}=$ Malda, $\mathbf{Y}_{4}=$ Amarpalli, $\mathbf{Y}_{5}=$ Wild,

$\mathbf{X}_{1}=$ Maximum Temperature $\left({ }^{0} \mathrm{C}\right) \quad ; \mathbf{X}_{2}=$ Minimum Temperature $\left({ }^{0} \mathrm{C}\right) ; \mathbf{X}_{3}=$ Morning Relative Humidity $(\%) ; \mathbf{X}_{4}=$ Evening Relative Humidity $(\%) ; \mathbf{X}_{5}=$ Total Rainfall $(\mathbf{m m})$

\section{Conclusions}

The adult hoppers of Amritodus atkinsoni (Leth.) appeared with the emergence of panicle and the peak of population was observed during FebruaryMarch in full bloom stage of the mango tree and the second peak in August-September on wild and all four cultivars under investigations. After this the insect migrated to cracks and crevices of tree trunk for hibernation. This indicates that it has two breeding seasons and hence two generations i.e., spring generation and summer generation, the former being more destructive than the latter. Mean maximum and minimum temperature showed significant positive correlation with the growth of hopper population whereas relative humidity (both morning and evening) revealed significant negative impact. Rainfall remained fluctuating thus had no influence on the growth of hopper population.

\section{References}

Anitha Kumari, D., Lakshmi, B.K.M., Reddy, G.S. and Reddy, M.L., 2009. Influence of abiotic factors on the incidence of hopper and chemical control strategies in mango. Karnataka J. Agri. Sci., 22: 601-602.

Anon., 2010. Manual for mango pest surveillance. National Centre for Integrated pest management, New Delhi. p 1.

Anufriev, G.A., 1970. Descriptioin of a new genus Amritodus atkinsoni (Leth.) (Jassidae: Homoptera) in South India. $\boldsymbol{J}$. Nat. Hist., 4: 375-376.

Ayyar, T.V.R., 1940. Handbook of Economic Entomology for South India. Govt. Press, Madras, 88-90.

Ayyar, T.V.R., 1963. Handbook of Economic Entomology for South India. Controller of stationary and printing. Govt. of Tamil Nadu, Madras pp. 267-269.
Babu, L.B., Maheshwari, T.M. and Rao, N.V., 2002. Seasonal incidence and biology of the mango hopper, Amritodus atkinsoni (Leth.) (Homoptera : Cicadellidae). Entomon., 27 (1): 35-42.

Bindra, O.S., Singh, B., Chahal, B.S. and Sekhon, S.S., 1971. Aerial application of insecticides for the control of mango hopper. PANS, 17 (3): 350-353.

Butani, D.K., 1974. Insect pests of fruit crops and their control, mango. Pesticides, 8 (3): 36-41.

Butani, D.K., 1979. Insects and Fruits. Periodical Expert Book Agency, Delhi: 112-114.

Butani, D.K., 1993. Mango Pest Problems. Periodical Expert Book Agency, New Delhi: 38-43.

Chari, S.N., Seshadri, H.S. and Patel, H.K., 1969. Control of mango hoppers. Pesticides, 3 (12): 33-35.

Chauhan, B.K. and Dabas, H.K., 1997. NHB Production Year Book. National Horticulture Board, New Delhi: 129.

Cheema, G.S., Bhat, S. and Naik, K.C., 1954. Commercial Fruits of India. Macmillan and Co. Ltd., Calcutta: 422.

Dalvi, C.S. and Dumbre, R.B., 1994. Breeding and seasonal incidence of mango hoppers. Bull. Entomol., New Delhi, 35 (1): 1-10.

Dwivedi, S.C., Singh, S.M.R. and Katiyar, R.R., 2003. Seasonal incidence of insect pest associated with mango crop. Ann. Plant Prot. Sci., 11(1): 159-162.

Fletcher, M.J. and Dangerfield, P.C., 2002. Idioscopus clypealis (Leth.), a second new leaf hopper pest in Australia (Hemiptera, Cicadellidae : Idiocerinae). Australian J. Entomol., 41(1): 35-38.

Fletcher, T.B., 1916. One hundred notes on Indian insects. Imperial Agricultural Research Institute Pusa (Bihar). Bulletin 59: 88-92.

Gangolly, S.R., Singh, R., Katyal, S.L. and Singh, D., 1957. The Mango. ICAR, New Delhi: 530. 
Ghauri, M.S.K., 1967. New mango leaf hoppers from the Oriental and Austro-Oriental regions (Homoptera: Cicadelloidea). Proc. R. Entomol. Soc. London (B), 36 (12): 159-166

Haseeb, M., 1998. In (proc.) National symposium on mango production and export, Lukhnow, June 25-27, Central institute for Subtropical Horticulture, Lukhnow, p.54.

Hiremath, S.C. and Hiremath, I.G., 1994. Studies on seasonal incidence and nature of damage of mango hoppers. Bull. Entomol., 35 (1): 78-83.

Hussain, M.A. and Pruthi, H.S., 1921. Preliminary note on winter spraying against mango hopper (Idiocerus spp.), vernacular name Tela. Report of Proc. of $4^{\text {th }}$ Entomological Meeting, Pusa (Bihar): 148-152.

Hussain, M.A. and Pruthi, H.S., 1924. Short note on the life history of the mango hoppers (Idiocerus spp.) in the Punjab. Report of Proc. of $4^{\text {th }}$ Entomological Meeting, Pusa (Bihar): 252-260.

Jhala, R.C., Shah, A.H., Patel, Z.P. and Patel, R.L., 1988. Studies on population dynamics of mango hopper and scope of off-seasonal spraying in IPM programme. Acta Horticulturae, 231: 597-601.

Joshi, P.C.and Kumar,S., 2012. Effect of some meteorological factors on seasonal abundance of Idioscopus nitidulus (Walker) (Hemiptera : Cicadellidae) in mango orchards of Haridwar (India).New York Science Journal 5 (12):101-103.

Kannan, M.and Rao, N. V., 2006. Ecological studies on mango hopper, Amritodus atkinsoni in Andhra Pradesh as a basis for IPM. Crop Res., 32 : 235-238.

Kayashima, I., 1934. On the damage caused by leaf hoppers to useful trees in Formosa, Taiwan. Rev. Appl. Entomol., 22(A): 376 .

Khan, H., 1939. A note on the change in the status of mango hopper (Idiocerus clypealis, Jassidae) in North Sindh. Indian J. Entomol., 1 (1): 53-54.

Lefroy, H.M., 1906. Indian Insect Pests. Today and Tomorrow Printers and publishers, New Delhi.786p.

Mackenna, J., 1919. Report on the Progress of Agriculture in India for 1917-18, Calcutta: 85-99.

Nair, M.R.G.K., 1975. Insects and Mites of Crops in India. ICAR, New Delhi: 104-106.

Nayar, K.K., Ananthakrishnan, T.N. and David, B.V., 1976. General and Applied Entomology. Tata McGraw-Hill Publishing Co. Ltd., New Delhi: 584.

Palo, M.A. and Garcia, C.E., 1936. Further studies on the control of leafhoppers and tip borers on mango inflorescence. Philippine J. Agri., 6: 425-464.

Patel, G.A. and Talgiri, G.M. 1950. Crop Pests and How to Fight Them. Government of Bombay, Bombay: 126-145.

Patel, J.R., Sheikh, A.M. and Ratanpara, H.C., 1994. Seasonal incidence and effect of minimum temperature and vapour pressure on the population of mango hopper, Amritodus atkinsoni (Leth.) in middle Gujarat. Gujarat Agricultural Univ. Res. J., 20 (1): 5-8.
Patel, R.K., Patel, S.R. and Shah, A.H., 1973. Studies on sexratio, longevity and seasonal incidence of the mango hopper, Amritodus atkinsoni (Leth.) (Jassidae: Homoptera) in South Gujarat. Indian J. Entomol., 35(3): 255-257.

Patel, R.K., Patel, S.R. and Shah, A.H., 1975. Biology of mango hopper, Amritodus atkinsoni (Leth.) (Jassidae: Hemiptera) in South Gujarat. Indian J. Entomol., 37(2): 150-153.

Patel, R.K., Patel, S.R. and Shah, A.H., 1989. Population behaviour (sex-ratio) of mango hopper, Amritodus atkinsoni (Leth.) and their parasitisation under prevailing temperature and humidity under field condition in South Gujarat. Indian J. Entomol., 51(2): 211-215.

Patel, R.K., Patel, S.R. and Shah, A.H., 1990. Population behaviour (sex-ratio) of mango hopper, Amritodus atkinsoni (Leth.) (Jassidae: Homoptera) and their parasitism under prevailing temperature and humidity under field conditions in South Gujarat. Indian J. Entomol., 52(3): 393-396.

Pezhman, H. and Radjabi, G.H. 2002. Study on biology of handle hopper Idioscopus clypealis (Leth.) (Homoptera: Cicadellidae) in Honnozgon Province. Appl. Entomol. Phytopathol., 70 (1): 25-26.

Pruthi, H.S. and Batra, H.N. 1960. Important fruit pests of Northwest India. Indian Country Agri. Res. Bull., 80: 61-64.

Pushpalatha, S.Kathirvelu, C. and Nachiappan,R.M., 2008. Correlation of seasonal incidence of mango hopper Amritodus atkinsoni and weather parameters on certain varieties of mango. Indian J.Trop.Biodiver., 15:81-83.

Rahman, K.A., 1939. Important insect pests of mango and how to combat them. Punjab Fruit J., 3: 512-517.

Rahman,S.M.A.and Kuldeep., 2007. Mango hopper : Bioecology and management - a review. Agric.Rev.,28 (1):49-55.

Rao, Y.R.,1930. Mango hopper problems in South India. Agri. J. India, 25 (1): 17-25.

Reddy, D.B.,1968. Plant Protection in India. Allied Publishers, New Delhi: 219-261.

Sathiyanandan, V.K., Gowder, B.R. and Santhanaraman, T., 1972. Control of mango hoppers, Idiocerus sp. Abs. Proc. Third International Symp. Sub-Trop. and Trop. Hort.: 83-84.

Sen, A.C. and Prasad, D., 1954. Experiments with new synthetic insecticides for the control of mango hoppers in Bihar. Indian J. Entomol., 16: 234-236.

Sharma, B. and Sharma, S., 2011.Seasonal abundance of mango hopper, Amritodus atkinsoni (Leth.) (Jassidae : Homoptera) in different environmental conditions of Jammu region. J.Env.Bio-Sci. 25(1):81-83.

Sharma, S. and Sharma, B., 2009. Mango hoppers species composition and their relative abundance in different environmental conditions of Jammu region. Crop Res. 38 (1, 2 \& 3):104-108.

Sharma, S., 2002. Population dynamics of mango leaf hoppers in different environmental conditions of Jammu region. 
M.Phil dissertation submitted to University of Jammu, Jammu.

Sharma, S., Tara, J.S. and Sharma, B., 2010. Effect of abiotic factors on mango hopper, Idioscopus clypealis Leth. population in different climatic conditions of Jammu region. J.Env.Bio.Sci., 24(1):39-42.

Sheikh, A.M., Ratanpara, H.C., Patel, J.R. and Patel, S.N., 1993. Effect of weather on mango hopper population in middle Gujarat. Rainfed Agricultural Research Newsletter. $2: 2-3$

Singh, L.B., 1968. The Mango Botany, Cultivation and Utilization. Leonard Hill Ltd., London: 112-114.

Singh, R., 1992. Seasonal abundance and management of mango hoppers. M.Sc Thesis submitted to Punjab Agriculture University, Ludhiana: 40.

Sood, N.K., Singh, K. and Rathore, V.S., 1971. Correlation of population fluctuation of Idioscopus clypealis (Leth.) (Homoptera: Jassidae) with weather conditions. Indian J. Hort., 28 (12): 169-171.

Soomro, A., Khuhro, R and Ansari,H., 1987. Status of insects associated with mango blossom. Proc. Pakistan Congr. Zool., 5:123-125.

Srivastava, R.P. and Butani, D.K., 1972. Mango hopper menace. Entomologist Newsletter, 2 (2): 10-11.

Srivastava, R.P., 1997. Mango Insect Pest Management. Int. Book Distributing Co., Lucknow, India, pp. 134.Srivastava, R.P., 1998. Preface-Mango Cultivation. Int. Book Distributing Co., Lucknow, India
Talpur, M.A., Khuhro,R.D and Nizamani, I.A., 2002. Phenological relationship between mango hoppers Idioscopus spp. and mango inflorescence / fruit. Pakistan Journal of Applied Sciences.,2 (5):533-536.

Tandon ,V.K., 2001.Population dynamics and control of hoppers on mango (Mangifera indica L.).M Sc dissertation submitted to Sher-e-Kashmir University of Agricultural Sciences and Technology, Jammu (J\&K).

Tandon, P.L., Lal, B. and Rao, G.S.P., 1983. Prediction of mango hopper, Idioscopus clypealis (Leth.) population in relation to physical environmental factors. Entomon., 8 (3): $257-261$

Veeresh, G.K.,1989. Pest problems in mango - world situation. Acta Horticulturae, 231: 551-565.

Verghese, A. and Rao, G.S.P., 1987. Determination of relevant critical stages for the management of mango hopper, Idioscopus clypealis (Leth.). Indian J. Hort., 4(4): 280-283.

Vevai, E.J., 1969. Know your crops, its pest problems and control mango. Pesticides, 36 (12): 21-31.

Vijaya,L.K., Raji, R.D and Varma NRG., 2010. Influence of Abiotic Factors on panicle population of mango hoppers in selected mango varieties. Indian Journal of Plant Protection.,38 (2):122-125.

Wadhi, S.R. and Batra, H.N., 1964. Pests of tropical and subtropical fruit trees. Entomology in India: 227-260.

Wagle, P.V., 1934. The mango hoppers and their control in Konkan-Bombay Presidency. Agri. Livestalk, India, 4 (2): $176-188$ 